\title{
Tolerance to Zn deficiency and P-Zn interaction in wheat seedlings cultured in chelator-buffered solutions
}

\author{
WenXuan MAI ${ }^{1,2,3}$, XiaoHong TIAN $^{1 *}$, Willam Jeffery GALE ${ }^{1}$, XiWen YANG ${ }^{1}$, XinChun LU ${ }^{1}$ \\ ${ }^{1}$ College of Resources and Environment, Northwest A\&F University, Yangling 712100, China; \\ ${ }^{2}$ Xinjiang Institute of Ecology and Geography, Chinese Academy of Sciences, Urumqi 830011, China; \\ ${ }^{3}$ Graduate University of Chinese Academy of Sciences, Beijing 100049, China
}

\begin{abstract}
Zinc deficiency is a common constraint for wheat production in the regions with limited precipitation, particularly in the regions with high levels of available phosphate $(P)$ in soil. Two experiments were conducted using chelator-buffered nutrient solutions to characterize differences in tolerance to $\mathrm{Zn}$ deficiency among three winter wheat (Triticum aestivum L.) genotypes and to investigate the relationship between $\mathrm{P}$ and $\mathrm{Zn}$ nutrition in wheat species. Four indices, Zn efficiency, relative shoot-to-root ratio, total $\mathrm{Zn}$ uptake in shoot, and shoot dry weight were used to compare the tolerance to $\mathrm{Zn}$ deficiency among three wheat genotypes. The results indicated that the four indices could be used in breeding selection for $\mathrm{Zn}$ uptake-efficient genotypes. The genotype H6712 was the most tolerant to $\mathrm{Zn}$ deficient, followed by M19, and then X13. Specifically, H6712 had the highest Zn uptake efficiency among the three genotypes. The addition of $P$ to the growth medium increased $\mathrm{Zn}$ uptake and translocation from roots to shoots. Total $\mathrm{Zn}$ content of the wheat plant was $43 \%$ higher with $0.6 \mathrm{mmol} / \mathrm{L} \mathrm{P}$ treatment than that of control with $0 \mathrm{mmol} / \mathrm{L} P$ treatment. The $\mathrm{Zn}$ translocation ratios from roots to shoots were increased by $16 \%$ and $26 \%$ with $0.6 \mathrm{mmol} / \mathrm{L} \mathrm{P}$ treatment and $3 \mathrm{mmol} / \mathrm{L} \mathrm{P}$ treatment, respectively, compared with $0 \mathrm{mmol} / \mathrm{L} \mathrm{P}$ treatment. In contrast, high $\mathrm{Zn}$ concentrations in the growth medium inhibited $\mathrm{P}$ translocation from roots to shoots, but the inhibitive effects were not strong. Sixty-six percent of $P$ taken up by wheat plants was translocated to the wheat shoots at $0 \mu \mathrm{mol} / \mathrm{L}$ $\mathrm{Zn}$ treatment, while the percent was $60 \%$ at $3 \mu \mathrm{mol} / \mathrm{L} \mathrm{Zn}$ treatment. The result may be due to the fact that the wheat plants need more $\mathrm{P}$ than $\mathrm{Zn}$.
\end{abstract}

Keywords: chelator-buffered solution; tolerance to $\mathrm{Zn}$ deficiency; $\mathrm{P}$ and $\mathrm{Zn}$ interaction

Soil $\mathrm{Zn}$ deficiency is a widespread constraint for wheat (Triticum aestivum L.) production, particularly in arid and semiarid regions where soil $\mathrm{pH}$ value and $\mathrm{CaCO}_{3}$ content are high and organic matter content is low (Cakmak et al., 2001). Soil Zn deficiency reduced both grain yield and quality (Lombnas and Singh, 2003) and may lead to human $\mathrm{Zn}$ deficiency, especially in developing countries where diets are abundant in cereal-based foods and deficient in animal protein (Cakmak et al., 1999; Acklandand and Michalczyk, 2006).

Wheat is the most important grain crop in northern China. It is mainly planted on calcareous soil which has low level of available Zn. Yang et al. (2007) reported that Diethylenetriaminepentaacetic Acid (DTPA)- extractable $\mathrm{Zn}$ in the calcareous soil was average 0.37 $\mathrm{mg} / \mathrm{kg}$, whereas a critical value of $0.5 \mathrm{mg} / \mathrm{kg}$ is required for optimal wheat growth (Liu, 1994). The low level of $\mathrm{Zn}$ in soil has a negative effect on wheat yield and nutritional value.

Zinc efficiency means the ability of crop to grow and yield well in $\mathrm{Zn}$ deficient soil. Wheat genotypes differ greatly in the adaptation to $\mathrm{Zn}$-deficient soil conditions (Cakmak et al., 1997a, b). Therefore, selecting and breeding Zn-efficient genotypes has been recognized as the most logical approach for solving the problem of $\mathrm{Zn}$ deficiency in plants and humans

Received 2011-01-19; accepted 2011-03-09

* Corresponding author: XiaoHong TIAN (E-mail: txhong@hotmail.com) 
(Cakmak et al., 2001). The improvement of Zn efficiency in wheat has become a major task for plant breeders in many countries (Cakmak, 2002). The first step is to identify $\mathrm{Zn}$ efficient wheat genotypes from existing genetic resources (Cakmak et al., 2001).

Zinc deficiency is common in crops that are grown in areas with high level of available soil P (Bogdanovic et al., 1999). High level of available soil $\mathrm{P}$ can also reduce the bioavailability of $\mathrm{Zn}$ to humans by increasing the phytic acid content in cereal grain (Kuwano et al., 2006). For these reasons, understanding the relationship between $\mathrm{P}$ and $\mathrm{Zn}$ is an important component of effective agronomy practices to apply $\mathrm{P}$ fertilizer. The relationship between $\mathrm{P}$ and $\mathrm{Zn}$ in plants is complex and there are many conflicting reports in literatures (Orabi et al., 1985; Webb and Loneragan, 1988; Günes et al., 1999; Huang et al., 2000).

Soil-free culture systems can provide important information about the interaction between nutrients and plant roots that can not be obtained from field studies completely. However, $\mathrm{Zn}$ contamination in chemical reagents and low plant requirements make it difficult to simulate $\mathrm{Zn}$ deficient soils using traditional nutrient solutions (Yang et al., 1994). Chelator-buffered nutrient solution culture is an alternative method which uses a chelating agent such as N-(2-hydroxyethyl) ethylenediaminetriacetic acid (HEDTA) to buffer the free activity of micronutrients to appropriately low levels (Rengel, 1999). Chelator-buffered nutrient solutions offer two advantages. Firstly, chelator-buffered nutrient solutions can stabilize and maintain low micronutrient activity, thus mimicking the situation occurring in soil. Secondly, micronutrient stress of varying severity can be imposed predictably and reproducibly (Parker et al., 1992).

In this paper, we reported the results of two experiments which used chelator-buffered solutions to investigate the effect of $\mathrm{Zn}$ and $\mathrm{P}$ nutrition on wheat growth. The objective of the first experiment was to compare the tolerance to $\mathrm{Zn}$ deficiency among three winter wheat genotypes through four plant indices. The objective of the second experiment was to investigate the interrelationship between $\mathrm{P}$ and $\mathrm{Zn}$ nutrition in wheat plants.

\section{Materials and methods}

\subsection{Experiment 1}

Three winter wheat genotypes were grown in chelator-buffered solutions containing $0.5 \mu \mathrm{mol} / \mathrm{L}$ or 5 $\mu \mathrm{mol} / \mathrm{L} \mathrm{ZnSO}_{4} \cdot 7 \mathrm{H}_{2} \mathrm{O}$ (Norvell and Welch, 1993). The composition of the chelator-buffered solution without $\mathrm{Zn}$ is shown in Table 1. The three winter wheat genotypes in this experiment were Mianyang19 (M19), Han6172 (H6172) and Xinmai13 (X13) which were widely planted in China.

Table 1 Composition of chelator-buffered nutrient solution

\begin{tabular}{lclc}
\hline Reagent & $\begin{array}{c}\text { Concentration } \\
(\mu \mathrm{mol} / \mathrm{L})\end{array}$ & Reagent & $\begin{array}{c}\text { Concentration } \\
(\mu \mathrm{mol} / \mathrm{L})\end{array}$ \\
\hline $\mathrm{KNO}_{3}$ & 1,500 & $\mathrm{H}_{6} \mathrm{Mo}_{7} \mathrm{O}_{24}$ & 0.1 \\
$\mathrm{Ca}\left(\mathrm{NO}_{3}\right)_{2} \cdot 4 \mathrm{H}_{2} \mathrm{O}$ & 1,000 & $\mathrm{CuSO}_{4} \cdot 5 \mathrm{H}_{2} \mathrm{O}$ & 2.8 \\
$\mathrm{MgSO}_{4} \cdot 7 \mathrm{H}_{2} \mathrm{O}$ & 250 & $\mathrm{MnSO}_{4} \cdot \mathrm{H}_{2} \mathrm{O}$ & 3.0 \\
$\mathrm{H}_{3} \mathrm{BO}_{3}$ & 12.5 & $\mathrm{NiCl}_{6} \cdot 6 \mathrm{H}_{2} \mathrm{O}$ & 0.1 \\
$\mathrm{C}_{6} \mathrm{H}_{5} \mathrm{O}_{7} \mathrm{Fe} \cdot 5 \mathrm{H}_{2} \mathrm{O}$ & 20.0 & $\mathrm{~K}_{3} \mathrm{HEDTA}$ & 50.0 \\
$\mathrm{MES}$ & 5,000 & & \\
\hline
\end{tabular}

Notes: (1) 2-(N-morpholino) ethanesulfonic acid (MES) was adjusted to $\mathrm{pH}$ 6.1 with $\mathrm{KOH}$; (2) Equal molar amounts of $\mathrm{ZnSO}_{4} \cdot 7 \mathrm{H}_{2} \mathrm{O}$ and $\mathrm{K}_{3} \mathrm{HEDTA}$ were dissolved in water and allowed to stabilize for half an hour before use; (3) Macro- and micro-nutrient concentrations in the $1 / 2$ strength chelator-buffered solution were $50 \%$ of the amount shown in the table, but MES and $\mathrm{K}_{3}$ HEDTA concentrations were unchanged.

Uniform wheat seeds were selected from each genotype, immersed in distilled water $\left(55^{\circ} \mathrm{C}\right)$ for 15 min, and sterilized in $3 \% \mathrm{H}_{2} \mathrm{O}_{2}$ solution $(\mathrm{v} / \mathrm{v})$ for 10 min. After sterilization, the seeds were rinsed with distilled water to remove residual $\mathrm{H}_{2} \mathrm{O}_{2}$. The sterilized seeds were immersed in distilled water for $3 \mathrm{~h}$ and then cultured for $7 \mathrm{~d}$ on filter paper moistened with distilled water.

Seedlings of similar size were selected and transferred to $200 \mathrm{ml}$ buckets containing $1 / 2$ strength chelator-buffered solution (without $\mathrm{Zn}$ added). Each container was covered with plastic sheets; the sheets had four holes. Three seedlings were placed in each hole. The fourth hole was used for aeration.

Prior to grow in full strength chelator-buffered solution, the seedlings were pre-cultured in $1 / 2$ strength solution for $3 \mathrm{~d}$ in order to overcome transplanting stress. The full strength chelator-buffered solution contained either 0.5 or $5 \mu \mathrm{mol} / \mathrm{L} \mathrm{Zn}$ treatment. Zinc was added to the chelator-buffered solution in the form of $\mathrm{ZnSO}_{4} \cdot 7 \mathrm{H}_{2} \mathrm{O}$. Each $\mathrm{Zn}$ treatment was repli- 
cated four times. Nutrient solutions were continuously aerated with air pumps. The solutions were completely replaced every three days.

The containers were arranged on the top of a laboratory table in a randomized complete block design. The plants were exposed to $10 / 14 \mathrm{~h}$ light/dark cycle each day and the light intensity was $300 \mu \mathrm{mol} /\left(\mathrm{m}^{2} \cdot \mathrm{s}\right)$.

Four indices were used to compare the tolerance to $\mathrm{Zn}$ deficiency among wheat genotypes. They are: (1) Zn efficiency; (2) Relative shoot-to-root ratio at deficient conditions compared with normal $\mathrm{Zn}$ concentrations in the growth medium; (3) Total uptake of $\mathrm{Zn}$ in shoot under $\mathrm{Zn}$ deficient treatment; and (4) shoot dry weight under $\mathrm{Zn}$ deficient treatments.

\subsection{Experiment 2}

Two winter wheat genotypes were grown in chelator-buffered solutions containing two $\mathrm{Zn}$ concentrations and three $\mathrm{P}$ concentrations in a $2 \times 3$ factorial design. The $\mathrm{ZnSO}_{4} \cdot 7 \mathrm{H}_{2} \mathrm{O}$ concentrations were $0 \mu \mathrm{mol} / \mathrm{L}$ and $3 \mu \mathrm{mol} / \mathrm{L}$, and the $\mathrm{NH}_{4} \mathrm{H}_{2} \mathrm{PO}_{4}$ concentrations were $0 \mathrm{mmol} / \mathrm{L}, 0.6 \mathrm{mmol} / \mathrm{L}$ and $3 \mathrm{mmol} / \mathrm{L}$, respectively. Each of the six treatment combinations was replicated three times. Two winter wheat genotypes, Yuanfeng 998 (Y998) and Zhengmai 9023 (Z9023) were used in this experiment. The selection and germination of seeds and the conditions for the culture of seedlings in the chelator-buffered solutions were the same as described in experiment 1 .

\subsection{Chemical analyses}

Plants from both experiments were harvested after 30 days of culture in the chelate buffered solutions. Excess water was removed by blotting, and the shoots and roots were dried in an oven at $75^{\circ} \mathrm{C}$. Shoot and root dry weights were recorded, and the plant samples were ground and dry-ashed at $550^{\circ} \mathrm{C}$ for $8 \mathrm{~h}$ in a muffle furnace. The ash was dissolved in $1: 1(\mathrm{v} / \mathrm{v})$ concentrated $\mathrm{HNO}_{3}$ solution. Shoot and root $\mathrm{Zn}$ concentrations in the solutions were determined by atomic absorption spectroscopy (AA320CRT, CANY Co., Ltd., China). Shoot and root $\mathrm{P}$ concentrations in the solutions were determined colorimetrically at $660 \mathrm{~nm}$ (UV-7502, CANY Co., Ltd., China) (Bao, 1999).

\subsection{Data analyses}

Zinc efficiency (\%) was calculated according to the method of Torun et al. (2000):
$\mathrm{Zn}$ efficiency=Shoot dry weight at the $\mathrm{Zn}_{0.5}$ treatment/Shoot dry weight at the $\mathrm{Zn}_{5.0}$ treatment $\times 100 \%$.

Zinc translocation ratio (\%) was calculated according to the method of Rengel et al. (1995a, b):

$\mathrm{Zn}$ translocation ratio $=$ Shoot $\mathrm{Zn}$ content/whole plant $\mathrm{Zn}$ content $\times 100 \%$.

Data from the two experiments were statistically analyzed with SAS 8.1 (SAS Institute Inc., Cary, NC, USA). Multiple comparisons of the means were conducted using Duncan's new multiple range test (SSR).

\section{Results}

\subsection{Zn deficiency and $\mathbf{P}$ toxicity symptoms among wheat genotypes}

In experiment 1 , wheat plants at $0.5 \mu \mathrm{mol} / \mathrm{L} \mathrm{Zn}$ treatment showed obvious $\mathrm{Zn}$ deficiency symptoms after one week of culture. Visual symptoms included intervening chlorosis between the mid-vein and leaf margin of young leaves, while the leaf tip, base and margin remained green. Wheat shoot dry weights was decreased ranging from $51 \%$ to $68 \%$ at $0.5 \mu \mathrm{mol} / \mathrm{L} \mathrm{Zn}$ treatment compared with $5 \mu \mathrm{mol} / \mathrm{L} \mathrm{Zn}$ treatment, while root dry weights was decreased ranging from $43 \%$ to $57 \%$ (Table 2). The decrease of shoot and root dry weight due to $\mathrm{Zn}$ deficiency was the smallest for H6172 and the largest for X13. The shoot-to-root ratios at $0.5 \mu \mathrm{mol} / \mathrm{L} \mathrm{Zn}$ treatment were decreased ranging from $15 \%$ to $28 \%$ compared with $5 \mu \mathrm{mol} / \mathrm{L} \mathrm{Zn}$ treatment which indicated that the inhabitation of $\mathrm{Zn}$ deficiency to the growth of wheat shoots was higher than that of wheat roots.

In experiment 2, the plants at $0 \mu \mathrm{mol} / \mathrm{L} \mathrm{Zn}$ and $3 \mathrm{mmol} / \mathrm{L} \mathrm{P}$ treatments developed chlorosis and necrosis at the tips and margins of old leaves, which indicated slight $\mathrm{P}$ toxicity. Other researchers reported that it was difficult to distinguish between $\mathrm{Zn}$ deficiency and $\mathrm{P}$ toxicity symptoms in a number of species (Loneragan et al., 1982). However, the visual differences between the two conditions were observed in the experiment.

\subsection{Tolerance of wheat genotypes to $\mathrm{Zn}$ deficiency}

In experiment 1 , the four indices were chosen to compare the response of the three wheat genotypes to $\mathrm{Zn}$ deficiency (Fig. 1). The four indices showed similar trends and indicated that $\mathrm{H} 6712$ was the most tolerant 
Table 2 Effects of $\mathrm{Zn}$ concentrations in chelator-buffered solutions on shoot and root dry weights ( $\mathrm{g} / \mathrm{plant}$ ) and shoot/root ratio of three wheat genotypes

\begin{tabular}{|c|c|c|c|c|c|c|}
\hline \multirow{3}{*}{ Parameters } & \multicolumn{2}{|c|}{ M19 } & \multicolumn{2}{|c|}{ H6172 } & \multicolumn{2}{|c|}{$\mathrm{X} 13$} \\
\hline & \multicolumn{6}{|c|}{$\mathrm{ZnSO}_{4} \cdot 7 \mathrm{H}_{2} \mathrm{O}$} \\
\hline & $0.5 \mu \mathrm{mol} / \mathrm{L}$ & $5 \mu \mathrm{mol} / \mathrm{L}$ & $0.5 \mu \mathrm{mol} / \mathrm{L}$ & $5 \mu \mathrm{mol} / \mathrm{L}$ & $0.5 \mu \mathrm{mol} / \mathrm{L}$ & $5 \mu \mathrm{mol} / \mathrm{L}$ \\
\hline Shoot dry weight (g/plant) & $0.275 b c$ & $0.705 \mathrm{ab}$ & $0.315 \mathrm{c}$ & $0.643 \mathrm{ab}$ & $0.283 \mathrm{bc}$ & $0.910 \mathrm{a}$ \\
\hline Root dry weigh (g/plant) & $0.086 \mathrm{c}$ & $0.175 b c$ & $0.112 b c$ & $0.195 \mathrm{ab}$ & $0.118 \mathrm{bc}$ & $0.273 \mathrm{a}$ \\
\hline Shoot/root & $3.19 \mathrm{~b}$ & $4.04 \mathrm{a}$ & $2.81 \mathrm{~b}$ & $3.30 \mathrm{ab}$ & $2.39 \mathrm{~b}$ & $3.33 \mathrm{ab}$ \\
\hline
\end{tabular}

Note: Data are from experiment 1; M19, H6172, and X13 represent Mianyang19, Han6172 and Xinmai13 wheat genotypes, respectively. The differences were first tested using one-way analysis of variance (ANOVA), and then multiple comparisons of the means within each Zn treatment were used. Within a column, the means followed by different letters are significantly different $(P<0.05)$.

to $\mathrm{Zn}$ deficient treatment followed by M19 and X13. Specifically, H6712 had the highest Zn efficiency the three genotypes. Due to $\mathrm{Zn}$ deficiency, the decrease of shoot dry weight for $\mathrm{H} 6712$ with 0.5 and $5 \mu \mathrm{mol} / \mathrm{L} \mathrm{Zn}$ treatments was less than that of the other two genotypes. Meanwhile, the genotype H6712 had the highest relative shoot-to-root ratio, total plant $\mathrm{Zn}$ content and shoot dry weight. The consistent results of the four indices showed that characterizing the tolerance of wheat plants to $\mathrm{Zn}$ deficiency is useful. Moreover, three of the four indices showed large differences among the three genotypes. For example, Zn efficiency of $\mathrm{H} 6712$ was $58 \%$ higher than that of X13. The results indicated that the three genotypes differed in tolerance to $\mathrm{Zn}$ deficiency, suggesting that H6172 might have the potential in breeding and selection for $\mathrm{Zn}$ efficient wheat genotypes.

\section{3 $P$ and $\mathrm{Zn}$ nutritional status of wheat plants}

2.3.1 Effect of $\mathrm{P}$ supply on the $\mathrm{Zn}$ concentration and content in wheat plants

The root $\mathrm{Zn}$ concentrations $(\mu \mathrm{g} / \mathrm{g})$ tended to decline as
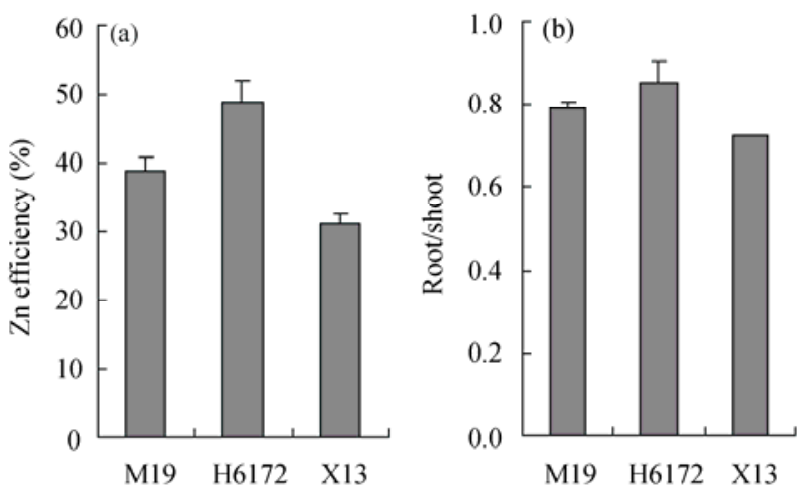

the $\mathrm{P}$ concentrations increased in the chelator-buffered solutions (Fig. 2a). In contrast, the shoot $\mathrm{Zn}$ concentrations increased significantly as the $\mathrm{P}$ concentrations increased. The change of shoot and root $\mathrm{Zn}$ contents $(\mu \mathrm{g} / \mathrm{plant})$ have similar trend with shoot and root $\mathrm{Zn}$ concentrations (Fig. 2b). This indicated that $\mathrm{P}$ decreased $\mathrm{Zn}$ uptake by plant root. The total $\mathrm{Zn}$ content of the wheat plants was $43 \%$ higher at $0.6 \mathrm{mmol} / \mathrm{L} \mathrm{P}$ treatment than that at $0 \mathrm{mmol} / \mathrm{L} \mathrm{P}$ treatment (control). Total $\mathrm{Zn}$ content at $3 \mathrm{mmol} / \mathrm{L} \mathrm{P}$ treatment was slightly smaller than that at $0.6 \mathrm{mmol} / \mathrm{L} \mathrm{P}$ treatment. The root $\mathrm{Zn}$ content was decreased by $19 \%$ at $3 \mathrm{mmol} / \mathrm{L} \mathrm{P}$ treatment than that of the control. This indicated that high $\mathrm{P}$ concentration in the nutrient solution resulted in the decrease of $\mathrm{Zn}$ uptake in wheat plants. The $\mathrm{Zn}$ translocation ratio from roots to shoots increased by $16 \%$ and $26 \%$ at $0.6 \mathrm{mmol} / \mathrm{L}$ and $3 \mathrm{mmol} / \mathrm{L} \mathrm{P}$ treatments, respectively (Fig. 2c), compared with the control. The result indicated that $\mathrm{P}$ promoted the translocation of $\mathrm{Zn}$ from roots to shoots. In conclusion, the
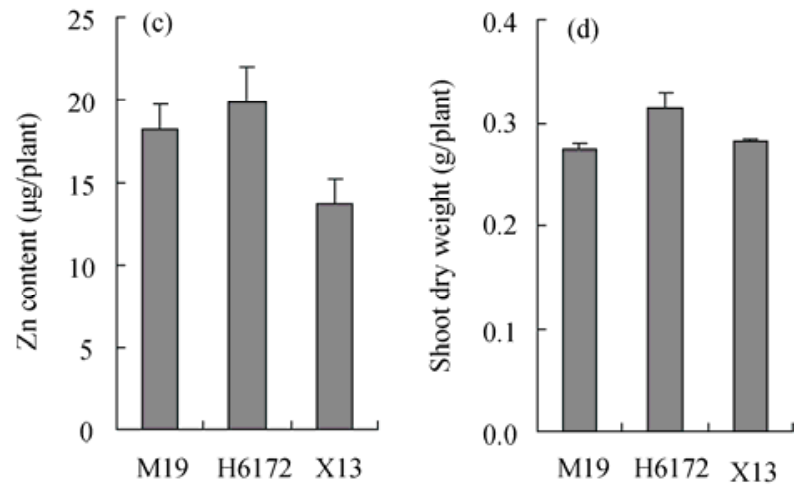

Fig. 1 Indices of experiment 1 characterized the tolerance to $Z n$ deficiency of different wheat genotypes. (a) $Z n$ efficiency; (b) shoo/root

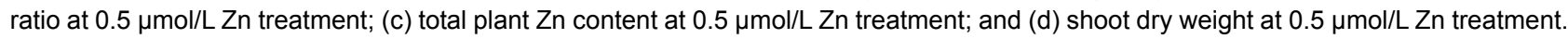
Data represent means \pm SD $(n=4)$. 

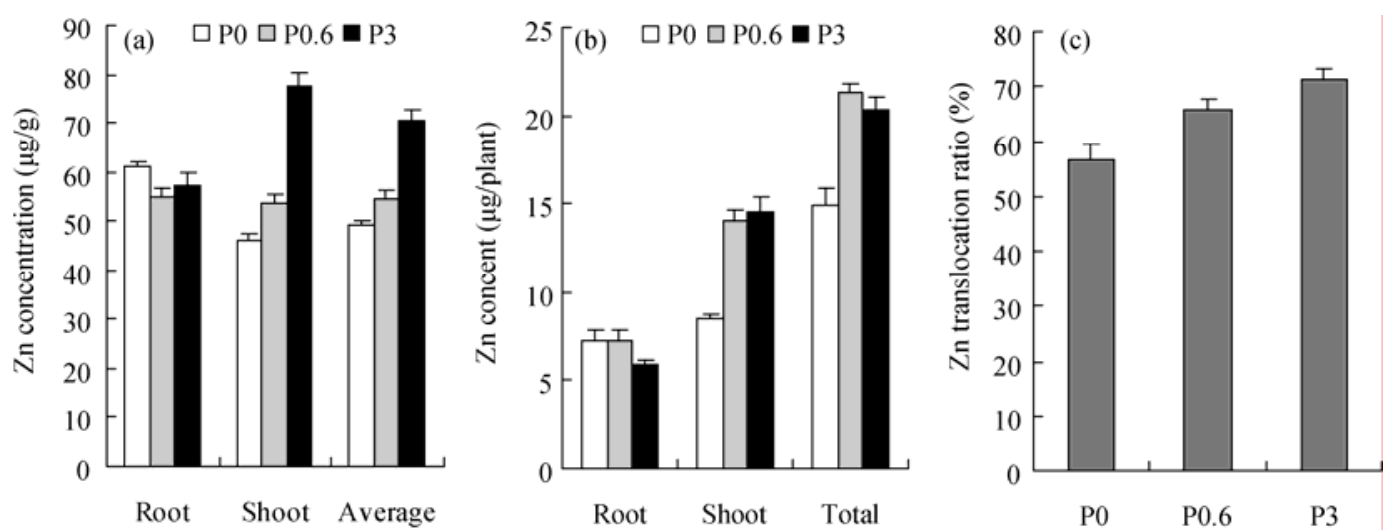

Fig. 2 Effects of $P$ addition in chelator-buffered solutions on (a) the $\mathrm{Zn}$ concentration in wheat shoots and roots; (b) the $\mathrm{Zn}$ content in wheat shoots and roots; and (c) the $\mathrm{Zn}$ translocation ratio. Data are from experiment 2 and represent the means of three genotypes \pm SD $(n=12)$.

results indicated that high $\mathrm{P}$ concentrations in the growth medium reduced $\mathrm{Zn}$ uptake but increased $\mathrm{Zn}$ translocation from roots to shoots.

2.3.2 Effect of Zn supply on the P concentration and content in wheat plants

The addition of $\mathrm{Zn}$ in the chelator-buffered solution resulted in a significant increase in the $\mathrm{P}$ concentration $(\mathrm{mg} / \mathrm{g})$ and content $(\mathrm{mg} / \mathrm{plant})$ in wheat shoots and roots (Fig. 3). The total plant $\mathrm{Zn}$ concentration was increased by $43 \%$ and the shoot $\mathrm{Zn}$ concentration was increased by $67 \%$ as the $\mathrm{P}$ concentration in the chelator-buffered solutions was increased from 0 to 3 $\mathrm{mmol} / \mathrm{L}$ (Fig. 2a). In contrast, the total plant $\mathrm{P}$ concentration was only increased by $14 \%$ and the shoot $P$ concentration was only increased by $10 \%$ as the $\mathrm{Zn}$ concentration in the nutrient solution was increased from 0 to $3 \mu \mathrm{mol} / \mathrm{L}$ (Fig. 3).
The addition of $\mathrm{Zn}$ in the chelator-buffered solutions resulted in a decrease in the proportion of plant $\mathrm{P}$ that was translocated from roots to shoots. At 0 $\mu \mathrm{mol} / \mathrm{L} \mathrm{Zn}$ treatment, $66 \%$ of the $\mathrm{P}$ taken up by wheat plants was translocated to the shoots (Fig. 3c). In contrast, $60 \%$ of the $\mathrm{P}$ taken-up by wheat plants was translocated to the wheat shoots at $3 \mu \mathrm{mol} / \mathrm{L} \mathrm{Zn}$ treatment. The results indicated that the increase of $\mathrm{Zn}$ concentration in the growth medium resulted in an increase of $\mathrm{P}$ uptake in wheat plants, however, the proportion of $\mathrm{P}$ that was translocated to the shoots was declined.

\subsection{3 $\mathrm{P} / \mathrm{Zn}$ ratios in wheat plants}

The supply of $\mathrm{Zn}$ in growth medium had different effects on the $\mathrm{P} / \mathrm{Zn}$ ratio in shoots compared with roots. The shoot $\mathrm{P} / \mathrm{Zn}$ ratio at $3 \mu \mathrm{mol} / \mathrm{L} \mathrm{Zn}$ treatment was lower than that at $0 \mu \mathrm{mol} / \mathrm{L} \mathrm{Zn}$ treatment (Fig. 4a). An
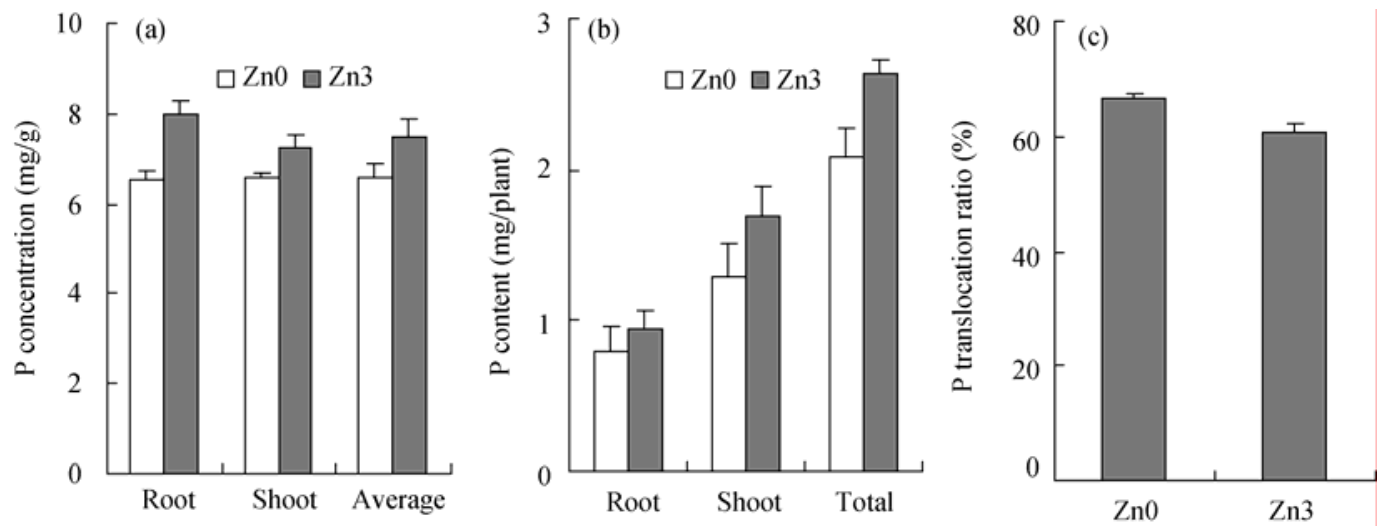

Fig. 3 Effects of $\mathrm{Zn}$ addition on (a) P concentration in shoots and roots, (b) P content in shoots and roots, and (c) P translocation ratio. Data are from experiment 2 and represent the means of two genotypes $\pm \operatorname{SD}(n=18)$. 

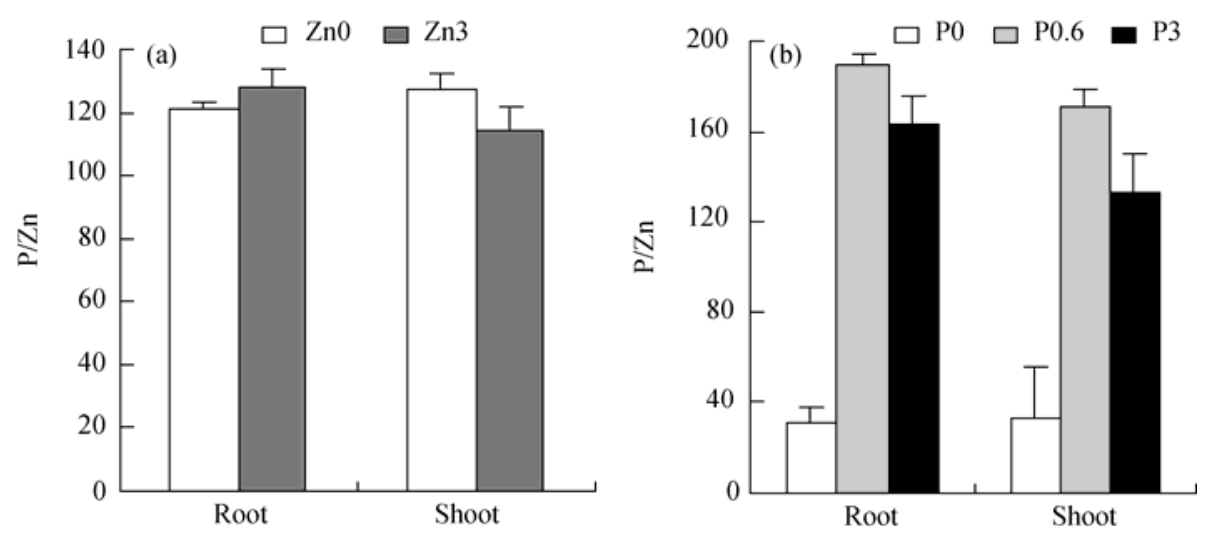

Fig. 4 Effects of $\mathrm{Zn}$ and $\mathrm{P}$ concentrations in chelator-buffered solutions on $\mathrm{P} / \mathrm{Zn}$ ratios in shoots and roots of wheat. Data are from experiment 2 and represent the means of two genotypes \pm SD ( $n=18$ for Fig. $4 \mathrm{a}$ and $n=12$ for Fig. 4 b).

opposite trend was found for the root $\mathrm{P} / \mathrm{Zn}$ ratio. The changes of $\mathrm{P} / \mathrm{Zn}$ ratio suggested that an increase of $\mathrm{Zn}$ concentrations in the growth medium resulted in an increase in $\mathrm{P}$ uptake by wheat roots but a decrease in $\mathrm{Zn}$ translocation from roots to shoots. At $0.6 \mathrm{mmol} / \mathrm{L} \mathrm{P}$ treatment, the $\mathrm{P} / \mathrm{Zn}$ ratios in shoots and roots were 4.2 to 5.1 times than that in the control, however, at 3 $\mathrm{mmol} / \mathrm{L} \mathrm{P}$ treatment, the values were decreased (Fig. $4 b)$. The results indicated that the effect of $\mathrm{Zn}$ on the $\mathrm{P} / \mathrm{Zn}$ ratio of wheat shoots and roots in the growth medium was greater than that of $P$.

\section{Discussion and conclusion}

Interactions between the elements in the soil-plant system affect many processes including absorption, translocation, distribution, accumulation, and physiological activity (Zhang et al., 2005). The relationship between $\mathrm{Zn}$ and $\mathrm{P}$ in plant nutrition has been widely studied, however, many results were inconsistent (Orabi et al., 1985). Shang and Bates (1987) found that $\mathrm{P}$ increased $\mathrm{Zn}$ deficiency in corn without $\mathrm{Zn}$ treatments, and $\mathrm{Zn}$ increased $\mathrm{P}$ deficiency in plants without $\mathrm{P}$ treatments. The deficiency in either case was readily corrected by applying the appropriate element. In contrast, Orabi et al. (1985) showed that the relationship between the two elements was positively correlative. The application of $\mathrm{P}$ increased the dry matter of the different parts of corn plant, meanwhile, $\mathrm{Zn}$ uptake and $\mathrm{Zn}$ content of corn plant were also increased. The large number of studies on the $\mathrm{Zn}$ and $\mathrm{P}$ relationship in the nutrition of plants and the great controversy about the obtained results showed that the problem has still not completely be solved, and also indicated that the problem is complex. Our results showed that neither a positive relationship nor a passive relationship existed between $\mathrm{Zn}$ and $\mathrm{P}$ uptake by wheat plants. High $\mathrm{P}$ concentrations (3 $\mathrm{mmol} / \mathrm{L}$ ) in the chealator-buffered solutions resulted in the slight decrease in $\mathrm{Zn}$ uptake by plant roots compared with $0.6 \mathrm{mmol} / \mathrm{L} \mathrm{P}$ treatment, however, the difference between the treatments was not significant. At the same time, the high $P$ concentrations promoted the translocation of $\mathrm{Zn}$ from roots to shoots, which is different from the above mentioned results. One explanation is that high $\mathrm{P}$ concentrations in the chelator-buffered solutions inhibited wheat root growth. And, $\mathrm{Zn}$ was transported from the roots to shoots in order to meet the metabolic needs of the plants. Another explanation is that the proper $\mathrm{P} / \mathrm{Zn}$ balance in metabolically active between root and shoot was different. $\mathrm{P}$ decreased $\mathrm{Zn}$ uptake in all plants, but the decrease was more significant in vegetative parts than in grain (Shukla and Hans, 1980). It is recognized that major interactions between $\mathrm{Zn}$ and $\mathrm{P}$ occur at the plant metabolic level, and a metabolic disorder within plant cells is related to an imbalance between $\mathrm{P}$ and $\mathrm{Zn}$. Therefore, the maintenance of a proper $\mathrm{P} / \mathrm{Zn}$ balance in metabolically active plant tissues for normal growth is necessary.

In contrast, the high $\mathrm{Zn}$ concentration in the nutrient solution increased $\mathrm{P}$ uptake by roots but reduced $\mathrm{P}$ translocation from roots to shoots. Our results are in agreement with Gianquinto et al. (2000) who found that the addition of small amount of $\mathrm{Zn}$ fertilizer increased $\mathrm{P}$ concentration in dwarf beans. And, it also 
revealed that the $\mathrm{Zn}$ and $\mathrm{P}$ interactions originate in the wheat plant roots.

Wheat plants maintained a narrower $\mathrm{P} / \mathrm{Zn}$ ratio which responded less to the application of $\mathrm{Zn}$. However, the effect of $\mathrm{P}$ on plant $\mathrm{Zn}$ uptake in the growth medium was significantly greater than that of $\mathrm{Zn}$. Thus, the $\mathrm{P}$ concentration in wheat plant plays a dominant role in maintaining the $\mathrm{P}$ and $\mathrm{Zn}$ nutritional balance in the plants. This opinion is indicated by the large difference in the $\mathrm{P} / \mathrm{Zn}$ ratios between the 0 and $0.6 \mathrm{mmol} / \mathrm{L} \mathrm{P}$ treatments. The $\mathrm{Zn}$ concentration in the growth medium affected the $\mathrm{P} / \mathrm{Zn}$ ratio in plants by inhibiting $\mathrm{P}$ translocation from roots to shoots, however, this effect was relatively small. These results showed that $\mathrm{Zn}$ response pattern in wheat plants was partly associated with their capacity to accumulate and distribute $\mathrm{P}$ in different plant tissues as reported by

\section{References}

Ackland M L, Michalczyk A. 2006. Zinc deficiency and its inherited disorders - a review. Genes \& Nutrition, 1(1): 41-50.

Ambler J E, Brown J C. 1969. Cause of differential susceptibility to zinc deficiency in two varieties of navy beans (Phaseolus vulgaris L.). Agronomy Journal, 61(1): 41-43.

Bao S D. 1999. Analysis of Agricultural Chemistry in Soil. Beijing: Chinese Agricultural Press, 268-281.

Bogdanovic D, Ubavic M, Cuvardic M. 1999. Effect of phosphorus fertilization on $\mathrm{Zn}$ and $\mathrm{Cd}$ contents in soil and corn plants. Nutrient Cycling in Agroecosystems, 54(1): 49-56.

Cakmak I, Derici R, Torun B, et al. 1997a. Role rye chromosomes in improvement of zinc efficiency in wheat and triticale. Plant and Soil, 196(2): 249-253.

Cakmak I, Ekiz H, Yilmaz A, et al. 1997b. Differential response of rye, triticale, bread wheat, and durum wheats to zinc deficiency in calcareous soils. Plant and Soil, 188(1): 1-10.

Cakmak I, Kalayci M, Ekiz H, et al. 1999. Zinc deficiency as a practical problem in plant and human nutrition in Turkey: a NATO-science for stability project. Field Crops Research, 60(1-2): 175-188.

Cakmak O, Ozturk L, Karanlik S, et al. 2001. Tolerance of 65 durum wheat genotypes to zinc deficiency in a calcareous soil. Journal of Plant Nutrition, 24(11): 1831-1847.

Cakmak I. 2002. Plant nutrition research: priorities to meet human needs for food in sustainable ways. Plant and Soil, 247(1): 3-24.

Cakmak I. 2008. Enrichment of cereal grains with zinc: agronomic or genetic biofortification? Plant and Soil, 302(1-2): 1-17.

Gianquinto G, Abu-Rayyan A, Di Tola L, et al. 2000. Interaction effects of phosphorous and zinc on photosynthesis, growth and yield of dwarf bean growth in two environments. Plant and Soil, 220(1-2):
Ambler and Brown (1969) by using two cultivars of soybean and cowpea, respectively.

Chelator-buffered nutrient solutions provided important information about plant roots, which is difficult to be obtained in field studies. We found that $\mathrm{P}$ in the growth medium increased $\mathrm{Zn}$ uptake and translocation from roots to shoots, while excess $\mathrm{Zn}$ in the growth medium affected the distribution of $\mathrm{P}$ in wheat plants by inhibiting $\mathrm{P}$ translocation from roots to shoots. Further studies need to be done to understand the complex relationship between $\mathrm{Zn}$ and $\mathrm{P}$ in plant roots.

\section{Acknowledgements}

This study was financially supported by National Natural Science Foundation of China (40971179 and 31071863) and the New-Century Excellent Talent Program of the Education Ministry of China (NCET-06-0866).

219-228.

Günes A, Inal A, Alpaslan M, et al. 1999. Effect of salinity on phosphorus induced zinc deficiency in pepper (Capsicum annuum L.) plant. Turkey Journal of Agriculture and Forestry, 23(4): 459-464.

Huang C Y, Barker S J, Langridge P, et al. 2000. Zinc deficiency up-regulates expression of high-affinity phosphate transporter genes in both phosphate sufficient and deficient barley roots. Plant Physiology, 124(1): 415-422.

Kuwano M, Ohyama A, Tanaka Y, et al. 2006. Molecular breeding for transgenic rice with low-phytic-acid phenotype through manipulating myo-inositol 3-phosphate synthase gene. Molecular Breeding, 18(3): 263-272.

Liu Z. 1994. Regularities of content and distribution of zinc in soils of China. Scientia Agricultura Sinica, 27(1): 30-37.

Lombnas P, Singh B R. 2003. Varietal tolerance to zinc deficiency in wheat and barley grown in chelator-buffered nutrient solution and its effect on uptake of $\mathrm{Cu}, \mathrm{Fe}$, and Mn. Journal of Plant Nutrition and Soil Science, 166(1): 76-83.

Loneragan J F, Grunes D L, Welch R M, et al. 1982. Phosphorus accumulation and toxicity in leaves in relation to zinc supply. Soil Science Society of American Journal, 46(2): 345-352.

Norvell W A, Welch R M. 1993. Growth and nutrient uptake by barley (Hordeum vulgare L. cv Herta): studies using an N-(2-Hydroxyethyl) ethylenedinitrilotriacetic acid-buffered nutrient solution technique (I. zinc ion requirements). Plant Physiology, 101(2): 619-625.

Orabi A A, El-Kobbia T, Fathi A I. 1985. Zinc-phosphorus relationship in the nutrition of corn plants (Zea mays L.) as affected by the total carbonate content of the soil. Plant and Soil, 83(2): 317-321.

Parker D R, Aguilera J J, Thomason D N. 1992. Zinc-phosphorus in- 
teractions in two cultivars of tomato (Lycopersicon escttlentum L.) grown in chelator-buffered nutrient solutions. Plant and Soil, 143(2): $163-177$.

Prasad A S. 2007. Zinc: mechanisms of host defense. Journal of Plant Nutrition, 137(5): 1345-1349.

Rengel Z, Graham R D. 1995a. Wheat genotypes differ in Zn efficiency when grown in chelator-buffered nutrient solution, I : growth. Plant and Soil, 176(2): 307-316.

Rengel Z, Graham R D. 1995b. Wheat genotypes differ in Zn efficiency when grown in chelator-buffered nutrient solution, II : nutrient uptake. Plant and Soil, 176(2): 317-324.

Rengel Z. 1999. Zinc deficiency in wheat genotypes grown in conventional and chelator-buffered nutrient solutions. Plant Science, 143(2): 221-230.

Shang C, Bates T E. 1987. Comparison of zinc soil tests adjusted for soil and fertilizer phosphorus. Fertilizer Research, 11(3): 209-220.

Shukla U C, Hans R J. 1980. Zinc response in pigeon pea as influenced by genotypic variability. Plant and Soil, 57(2-3): 323-333.
Torun B, Bozbay G, Gültekin I, et al. 2000. Differences in shoot growth and zinc concentration of 164 bread wheat genotypes in a zinc-deficient calcareous soil. Journal of Plant Nutrition, 23(9): 1251-1265.

Webb M J, Loneragan F. 1988. Effect of zinc deficiency on growth, phosphorus concentration, and phosphorus toxicity of wheat plants. Soil Science, 52(6): 1676-1680.

Yang X, Römheld V, Marschner H. 1994. Application of chelator-buffered nutrient solution technique in studies on zinc nutrition in rice plant (Oryza sativa L.). Plant and Soil, 163(1): 85-94.

Yang X E, Chen W R, Feng Y. 2007. Improving human micronutrient nutrition through biofortification in the soil-plant system: China as a case study. Environmental Geochemical Health, 29(5): 413-428.

Zhang F C, Kang S Z, Gong D Z, et al. 2005. Maize growth and phosphorous and zinc uptake under different phosphorous supply levels. Chinese Journal of Applied Ecology, 16(5): 903-906.

Zhao X L, Wang Q, Zheng S J. 1999. A review about P-Zn antagonism. Chinese Journal of Soil Science, 30(3): 136-137.

\section{State Key Laboratory of Xinjiang Institute of Ecology and Geography was successfully founded}

Recently, State Key Laboratory of Desert and Oasis Ecology of Xinjiang Institute of Ecology and Geography (XIEG), Chinese Academy of Sciences, was approved by Ministry of Science and Technology of the People's Republic of China to be founded.

The laboratory will focus on the research fields including desert ecological processes and desertification prevention and control, oasis ecological processes and sustainable management, ecological and hydrological processes and water resources utilization, and mountain-oasis-desert ecosystem processes and regional integrated simulation. Meanwhile, the laboratory will intensify the researches of natural resources utilization and the relationship between ecological protection and economic development in arid land, in order to meet the need of social economic development and ecological construction in Western China. 